\title{
High School to University in Ontario: Did an Extra Year Make a Difference?
}

\section{PATRICK BRADY \& PHILIP ALLINGHAM Lakehead University}

\begin{abstract}
This study examined perceptions of preparedness for post-secondary education in the province of Ontario. Participants were 272 university students enrolled in the first year of a four-or five-year concurrent teacher education program and represented two distinctive groups: (a) entrants who had completed the old five-year Ontario Academic Credit system, and (b) those who were admitted to university via the new four-year program. They responded to a questionnaire which inquired into the degree to which they believed that their final year of secondary school had adequately prepared them for the transition to university level studies. Although data analysis did not reveal any significant difference between the two groups in terms of academic achievement, Grade 12s reported feeling less prepared overall for the challenges of university, especially in terms of the acquisition of specific academic skills, as well as adjustment to the university social milieu.
\end{abstract}




\section{RESUMÉ}

Cette étude examine les perceptions de la préparation pour l'université dans la province d'Ontario. Les défenduers, 272 étudiants de l'université dans l'année d'une programme à quatre années ou à cinq années pour l'education des proffesseurs, et représenter deux groups differéntes: les entrantes qui prennent ses diplômes du système Acadèmique Crédit ancien pour Ontario, et (b) les entrantes qui prennent ses diplômes du système noveau Acadèmique Crèdit pour cette province. Ils on répondu à une questionnaire autour de comment ils croient que l'annèe final de la lycèe preparee eux le transition à l'université. Bien que l'analysis à data non révélee pas de differènce significante entre les deux groups à l'accomplissement académique. Ci-devant étudiants du grade douzième dirent se moins de preparer toutes les gageurses de l'université, surtout à l'acquistion des compétences académigue aussi l'adaption au milieu social de l'université.

In September of 1995 Ontario Minister of Education John Snobelen announced that, "Beginning immediately, we are going to develop a more focused, relevant and meaningful four-year secondary school system. This new system will come into effect for students entering Grade 9 in 1997" (Ontario Ministry of Education and Training [OMET], 1995). Although its implementation was eventually delayed until September of 1999, this initiative marked the culmination of a more than fifty-year effort on the part of the province to bring its system of secondary education into line with the four-year model predominant in the rest of North America. The result was the creation of the famed "Double Cohort": two distinctive groups of students graduating from secondary school in the same year, the last of the old Ontario Academic Credit stream, and the first of the new Grade 12 graduates.

Apart from the logistical challenges created by the resultant potential doubling of the university applicant pool, the compression of the secondary school curriculum into four years also had other significant implications. For example, does the new and untested Grade 12 program of studies adequately prepare high school graduates for the academic challenges 
inherent to the transition to post- secondary education? Additionally, would entering university at an earlier age have any significant impact on students' academic achievement or social adjustment during the first year of university? The purpose of this study, therefore, is to examine the extent to which both components of the Double Cohort perceive that their final year of secondary school prepared them for the academic and social transition to university, and to ascertain the extent to which the perceptions of the two groups differ.

\section{THEORETICAL FRAMEWORK}

Chaskes (1996) provided a useful metaphor for the high schooluniversity transition phenomenon, a process he likened to the immigrant experience. First-year university students undergo a "resocialization process [that] involves culture shock, 'language' acquisition, and the internalization of academic, bureaucratic, and social norms as well as the values and expectations of the college milieu" (p. 79). As he observed, "the immigrant analogy is appropriate because it contains so many of the same elements encountered by students when making the transition to college" (p. 81). Just as immigrants often harbour preconceived notions regarding life in their adoptive countries, first-year students often arrive on campus with pre-conceptions concerning university life. Many of these pre-conceptions prove to be inaccurate or false when subjected to the harsh light of reality, the most common misperception being the efficacy of their secondary school preparation for university. Furthermore, just as new arrivals are expected to adapt to cultural milieu of their new homelands, first-year students are expected to adjust to the nuances of the institutions they are attending, an often daunting task given the size and bureaucratic complexity of many universities. Consequently, first-year students may experience a form of culture shock similar to that experienced by immigrants as they proceed with the process of negotiating the terms of their day-to-day existence within the university community.

In a similar vein, Tinto (1988) found that the secondary school to university transition process consisted of three distinctive stages: separation, transition and incorporation. In the case of the former, students are required to "disassociate themselves, in varying degrees, from 
membership in the past communities, most typically those associated with the local high school and place of residence" (p. 433). While this stage has the potential to create varying levels of stress among first-year students, it is nonetheless necessary to their full integration into the intellectual and social life of the receiving institution. The middle stage, as its name implies, is transitory in nature as newly arrived students find themselves in the process of severing their ties to their previous communities while not yet having established bonds with their new institution. The result for students can be a sense of loss and confusion that, in extreme cases, can present a barrier to persistence in university. The final stage, incorporation, is marked by the student becoming fully integrated into the culture of the university community, a task that is complicated by the fact that all-to-often first-year students are left to fend for themselves in learning the social, behavioral, and other norms of their new institutions. The result is often that some incoming students inevitably fail to incorporate themselves into the academic and social life of their university communities and leave higher education altogether.

\section{Factors that influence "transition anxiety"}

Researchers (Sanders \& Burton, 1996; Smith, 1997) have coined the term "transition anxiety" to describe the collective effects of such stressors as financial worries, professional goals, family demands and expectations, and even low self-esteem. A review of the relevant literature indicates that the following factors contributed to "transition anxiety" among first-year university students in Canada: (a) lack of social support; (b) being provided with insufficient information during secondary school regarding the realities of university life; and (c) insufficient peer support (which may be gained through involvement in institutionally-sponsored activities such as co-curricular clubs and sports).

Students living at home, for example, experience significantly less stress because their secondary-school friends and immediate family are available to provide a "buffer against the difficulties experienced when coping with the new environment and expectations of college life" (Johnson, 1995, p.345). First-year students living in residence in a largely 
"commuter" university tend to experience difficulties with making friends simply because the majority of students are from the community in which the institution is located, and therefore have an adequate number of friends already.

Furthermore, students tend to experience greater stress at the beginning of their first semester than at any other time of the year. Often, they are still sorting out their timetables, making expensive textbook purchases, negotiating transportation, looking for part-time work, and even looking for places to live early in September.

Holdaway and Kelloway (1987), having studied 937 first-year students at the University of Alberta, reported that the students generally felt that high school had not sufficiently prepared them for university with respect to time management, work load, level of difficulty of reading or writing assignments, study and library skills, and methods of instruction. The latter were found to include lectures in large, impersonal classes delivered by professors who were quite aloof when compared to their former high school teachers. The aforementioned researchers further reported that first-year students in Canada, the United States, Great Britain, and Australia whose academic performance fell below their expectations based on their prior high school achievement also experienced adjustment difficulties

Moreover, Larose et al. (1998), in citing American studies, correlated student satisfaction with personal and active involvement "in the learning process through organized study time, examination preparation, and independent study or research with faculty guidance" (p. 278). Students in certain faculties will tend to have greater access to instructors and greater opportunities to participate in research. However, for Canadian first-year students in "commuter" post-secondary institutions factors "such as high school marks, parental education, and involvement in university activities seem to be of little or no consequence in facilitating adjustment" (Grayson, 2003, p. 426). Moreover, "traditional" Canadian factors used to profile students who will manage the transition with relative ease such as gender, parents' levels of education, and even OAC grades are irrelevant, according to Grayson (2003). He concluded that "retention after first year is a function of academic success rather than social involvement" (p. 421). 
Finally, a review of the literature on the subject of the high schooluniversity transition suggests a number of areas for study among the "Double Cohort" population in Ontario post-secondary institutions. It is worthwhile, therefore, to inquire as to their ability to adjust to the academic and social aspects of university life. Areas of inquiry, according to the themes identified by the literature, include the following: handling the stress of increased reading and writing assignments, the degree to which high school has equipped students with the subject knowledge and study skills necessary for academic success at university, as well as the extent of their involvement in campus life. If significant differences were to emerge between the responses of Grade 12 and OAC graduates, reflecting not merely their age differences but differences in their secondary educations, one might conclude that the old and new curricula have not equally prepared these students for post-secondary studies.

\section{Eliminating the Fifth Year: The Long Road to Reform}

As previously indicated, Ontario had long been anomalous in North America in that it was the only educational jurisdiction that required its university-bound students to complete five years of secondary education. In order to comprehend fully the magnitude of the 1999 reforms one must appreciate just how deeply ingrained the fifth year of high school had become in the collective consciousness of the province.

Although the standard length of the Ontario system of public education was established at 13 years in 1921 (Fleming, 1971), the fifth year of secondary school for university-bound students was to survive numerous attempts at its abolition. Both the Royal Commission on Education in Ontario in 1950 (Government of Ontario, 1950) and the subsequent Report of the Provincial Committee in Aims and Objectives of Education in the Schools of Ontario in 1968 (Ontario Department of Education, 1968) recommended the adoption of a four-year secondary model. Furthermore, even the restructuring necessitated by the introduction of the OAC system in 1984, which gave university-bound students the option of completing their university entrance requirements in four years instead of five, failed to achieve its initial objective because relatively few students exercised that option (Casas \& Meaghan, 1996). As Gidney (1999) observed, 
"Death by starvation, in other words, didn't work; what grade 13 needed was a stake through the heart" (p. 101).

In the end that stake was wielded more of a result of fiscal pressures than any pedagogical rationale. Although yet another report, For the Love of Learning (Government of Ontario, 1994), had called for the abolition of the OAC year in 1994, it was the political agenda of the newly-elected Progressive Conservative government that spelled the end for the fifth year of high school in the province. Consistent with the Conservative's platform of economic expansion, tax reduction, fiscal restraint, and facing a substantial budgetary deficit, the Minister of Education revealed the government's true motivation when he announced in the legislature, "When the four-year program is fully implemented in 2001, savings for the taxpayers will amount to some $\$ 350$ million annually" (OMET, November, 1995).

In the end, recommendations by a number of government commissions aside, it was economics more than anything else that led to the elimination of the fifth year of secondary school. However, regardless of the merits of the case for abolition, only a comparison between the graduates of the old five-year and the new four-year programs will determine whether or not Grade 13/OAC had been worth preserving all those years.

\section{Significance of the Policy Change}

As previously stated, prior to the fall of 1999 Ontario occupied a unique position among the 60 plus major educational systems in North America in that it was the only jurisdiction to make a fifth year of formal secondary education available to its university-bound students. The aforementioned restructuring initiative, therefore, has particular significance due to two factors: the relationship between high school performance and academic achievement in the first year of university, as well as the role played by the secondary school in the onset of "transition anxiety".

Research (Pike \& Saupe, 2002; Harackiewicz, Baron, Tauer \& Elliot, 2002) has pointed to the existence of a strong linkage between a student's academic performance during high school and his or her ultimate success in university level studies. This also appears to have been the case in Ontario, where Allan, Darling, Hughes and Rosenfeld (1983) found a 
strong correlation between students' grade 13 marks and their grades during the first year of university. Given the replacement of the OAC system, a series of courses specifically designed for university preparation, with a new untested curriculum plus the province's prior long standing mindset regarding the necessity of a fifth year of high school, it is reasonable to speculate as to whether or not this reform initiative has had an impact on the transition from high school to university.

Secondly, while high schools play a key role in the academic preparation of their charges for the challenges presented by post-secondary education, the very conditions that lead to success in the former may well hinder transition to the latter. As Jones and Frydenburg (1998) indicated, secondary schools tend to be "nurturing" environments where students have developed strong support systems among teachers/staff and peers, so that the prospect of being compelled to leave often contributes to the onset of transition anxiety, as evidenced by the phenomenon known as the "senior slump" (Brody, 1986). This reluctance to depart from the familiar appears to be particularly strong in Ontario, where a significant number of students have not only eschewed the opportunity to fast-track their high school studies ( Casas \& Meaghan , 1996), but have often elected to extend their secondary school educations beyond the fiveyear norm, essentially creating an unofficial grade 14 (Granger, 1994). It would be useful, therefore, to ascertain whether the reduction of the high school program to four years contributes to or detracts from the aforementioned anxiety.

\section{Participants}

\section{METHODS}

Participants were 272 students ( 200 women, 72 men) enrolled in the first year of a four or five-year concurrent teacher education program at a small Canadian university. As a consequence of the compulsory nature of the course, participants consisted of both potential elementary and secondary teachers, and represented a variety of subject majors and combinations of majors drawn from three of the university's six faculties. Participation was voluntary and anonymous with $272(86.9 \%)$ of 313 students completing the survey. 


\section{Instruments}

The primary instrument of inquiry was a survey questionnaire adapted from Sheppard's (1993) History Preparation Survey, and consisted of three parts. The first section elicited specific demographic information regarding participants' gender, age, route to university entrance, program major, grade-point average at the end of secondary school and at the end of the first semester of university, place of residence during the first semester, and hours spent engaged in paid employment.

The second section of the survey instrument examined respondents' perceptions regarding the degree to which they believed that their final year of high school had adequately prepared them for the challenges inherent to the transition to post-secondary education. This section included the following areas: (a) sufficient grounding in subject knowledge; (b) the acquisition of specific academic and study skills; and (c) adjustment to the university social milieu. Overall, 15 variables were identified and measured using a five-point Likert-scale inventory (" 5 = strongly agree" through " 1 = strongly disagree").

The questionnaire also included an open-ended response item that invited participants to answer the following question: "Is there anything else about the transition from high school to university that you would like to tell us?" A total of 128 (47.05\%) students chose to respond to this item.

\section{DATA ANALYSIS}

Both qualitative and quantitative techniques were employed in the analysis of the data generated by the questionnaire. Quantitative analysis consisted primarily of a T test utilized in order to determine whether or not there was a significant difference in the degree to which either sample group perceived that their final year of secondary school had prepared them for university-level studies. The two groups consisted of respondents who had entered university via the OAC track and those who had been admitted from the new Grade 12 program.

Qualitative data were derived from the open-ended response item that formed an integral component of the questionnaire. Respondents' 
comments were analysed and, as themes emerged, were coded with what Miles and Huberman (1994) referred to as "descriptive codes." Emergent themes included the following: the nature of participants' academic preparation for university studies; the perceptions of OAC and Grade 12 students regarding the extent to which they perceived that their final year of secondary school had prepared them for post-secondary education; participants' concerns regarding their adjustment to the social aspects of university life; and the extent to which respondents believed that they had developed sufficient life skills to facilitate their transition to university.

\section{Limitations}

1. The sample was restricted to first-year Concurrent Education students and, therefore, may not be representative of the wider university freshman student population.

2. Results represent the responses of students attending a specific institution at a given point in time, and therefore may not be generalizable to students at other institutions.

3. The limited sample size impinges on the viability of extrapolating the results to larger populations.

4. Given the disproportionate number of females in the sample, the results may be reflective of a gender bias.

\section{RESULTS}

\section{Participant Demographics}

As previously indicated, the sample consisted of 200 female (73.5\%) and 72 male (26.5\%) first-year students enrolled in a concurrent teacher education program at a small Ontario university. Of the total sample 160 $(58.8 \%)$ had been admitted to university via the OAC route, $86(31.6 \%)$ had completed the new four-year Grade 12 stream, and the remaining $26(9.6 \%)$ had been admitted either as mature students or as transfers from Early Childhood Education programs offered at the Community College level. As participants were admitted primarily on the basis of their secondary school grades, it is useful to examine further this aspect of the sample's characteristics. Of the 271 participants responding to this 
item, $182(67.2 \%)$ indicated that they had attained an overall average of at least $\mathrm{A}(100 \%-80 \%)$ during their final year of high school, compared to $75(27.7 \%)$ who reported grade-point averages of B (79\%-70\%). Survey data also indicated that the sample was evenly divided between those who chose to live in residence $(122,44.9 \%)$ and those living at home $(125,46.0 \%)$. An additional $23(9.2 \%)$ reported living off-campus but not at home. Finally, $130(48.1 \%)$ of the participants stated that they had not been engaged in paid employment during the first semester of their university studies, as opposed to $37(13.7 \%$ ) who had worked between one and nine hours per week, 69 (25.6\%) 10-19 hours, and 34 (12.6\%) who indicated that they had worked in excess of 20 hours a week during the period. It is significant to note, as illustrated in Table 1 that there were no statistically significant differences between OAC and Grade 12 graduates with regard to the aforementioned variables. There was, however, a significant difference with respect to the participants' ages. The mean age for OAC graduates was 19.17 years $(\mathrm{SD}=.6015)$ compared to 18.18 years $(\mathrm{SD}=.4481), t=-13.301, \mathrm{p}<.001$ for Grade 12 graduates.

\section{Participant Academic Adjustment to University}

In terms of academic achievement, as measured by self-reported end of first semester grade-point averages, there was no statistically significant difference between the OAC and Grade 12 cohorts. The mean for Grade 12 's was $3.89(\mathrm{SD}=.83)$ and $3.91(\mathrm{SD}=.75)$ for OACs, $t=-.25 \mathrm{NS}$. There were, however, significant differences between the two groups three areas: (a) the degree to which participants perceived that their final year of secondary school had provided them with adequate preparation for university level studies; (b) the extent to which respondents believed that they had acquired suitable note-taking skills; and (c) the degree to which participants felt that they had developed suitable independent research skills. Complete data analysis results are displayed in Table 2.

As illustrated in Table 2, participants who were admitted to the university via the $\mathrm{OAC}$ route were more likely to indicate their agreement with the statement "In general, my final year of high school prepared me for university studies" than were their Grade 12 counterparts. The mean 
Table 1

Participant Demographics by Entrance Stream

\begin{tabular}{|c|c|c|c|c|c|}
\hline \multirow[b]{2}{*}{ Variable } & \multicolumn{2}{|c|}{$\mathrm{OAC}$} & \multicolumn{2}{|c|}{ Grade 12} & \multirow[b]{2}{*}{$t$} \\
\hline & Mean & $\begin{array}{c}\text { Standard } \\
\text { Deviation }\end{array}$ & Mean & $\begin{array}{c}\text { Standard } \\
\text { Deviation }\end{array}$ & \\
\hline Gender & 1.70 & .46 & 1.78 & .42 & 1.33 \\
\hline $\begin{array}{l}\text { GPA at the en } \\
\text { of High } \\
\text { School }\end{array}$ & 4.65 & .58 & 4.68 & .47 & .44 \\
\hline $\begin{array}{l}\text { Domicile Firs } \\
\text { Semester }\end{array}$ & 3.45 & .60 & 3.35 & .22 & -1.23 \\
\hline $\begin{array}{l}\text { Hours of Paid } \\
\text { Work First } \\
\text { Semester }\end{array}$ & 3.93 & 1.19 & 4.09 & 1.02 & 1.07 \\
\hline Age & 19.19 & .60 & 18.19 & .45 & $-13.30^{*}$ \\
\hline
\end{tabular}

Note 1. Degrees of freedom for the $t$ tests were as follows: Gender 244, GPA 243, Domicile 244, Hours of paid work first semester 243, Age 243.

Note 2. Variable Categories are as follows: Gender: Male $=1$, Female $=2$; GPA: $5=\mathrm{A}$ $(80-100 \%), 4=\mathrm{B}(70-79 \%), 3=\mathrm{C}(60-69 \%), 2=\mathrm{D}(50-59 \%), 1=\mathrm{F}($ Below $50 \%)$; Domicile: $4=$ University Residence, $3=$ At Home, 2 = Off Campus, not at home, $1=$ Other; Hours of Paid Work: $5=$ Did not work, $4=1-9$ hours per week, $3=10-19$ hours per week $2=20-29$ hours per week, $1=30+$ hours per week; Age: Reported in years and months.

$* \mathrm{p}<.001$ (two-tailed tests)

for OAC graduates was $3.81(\mathrm{SD}=1.08)$ compared to $3.49(\mathrm{SD}=1.09)$, $t=2.18, \mathrm{p}<.05$ for Grade 12 's. These findings were confirmed by participant comments generated by the open-ended response item.

Participants who entered university via the Grade 12 route commented on two specific issues. First, a number of respondents conjectured that the compression of the secondary school curriculum into four years reduced their learning opportunities by largely confining their final-year options to those courses that were prerequisites for university admission, a situation that impacted on their first semester experience. 
Table 2

Perceptions of Academic Preparation for University

\begin{tabular}{|c|c|c|c|c|c|}
\hline \multirow[b]{2}{*}{ Variable } & \multicolumn{2}{|c|}{$\mathrm{OAC}$} & \multicolumn{2}{|c|}{ Grade 12} & \multirow[b]{2}{*}{$t$} \\
\hline & Mean & $\begin{array}{l}\text { Standard } \\
\text { Deviation }\end{array}$ & Mean & $\begin{array}{l}\text { Standard } \\
\text { Deviation }\end{array}$ & \\
\hline $\begin{array}{l}\text { General level of preparation } \\
\text { for university }\end{array}$ & 3.81 & 1.09 & 3.49 & 1.08 & $-2.17^{*}$ \\
\hline Subject content knowledge & 3.78 & 1.10 & 3.61 & .95 & -1.20 \\
\hline $\begin{array}{l}\text { Preparation for essay } \\
\text { writing }\end{array}$ & 3.38 & 1.24 & 3.35 & 1.28 & -.013 \\
\hline $\begin{array}{l}\text { Preparation for exams and } \\
\text { test taking }\end{array}$ & 3.25 & 1.22 & 3.05 & 1.16 & -1.26 \\
\hline Note taking skills & 3.37 & 1.28 & 2.78 & 1.21 & $-3.52 * *$ \\
\hline Research skills & 3.66 & 1.13 & 3.18 & 1.08 & $-3.22 * *$ \\
\hline Independent study skills & 3.89 & 1.03 & 3.79 & 0.94 & -.79 \\
\hline Amount of reading required & 2.75 & 1.29 & 3.75 & 1.26 & 0.02 \\
\hline Tutorial work & 3.04 & 0.89 & 2.92 & 0.83 & -1.08 \\
\hline Intimidated by class size & 2.41 & 2.08 & 2.39 & 1.21 & 0.74 \\
\hline
\end{tabular}

Note1: Degrees of freedom for $t$ tests were as follows: General level of preparation for university 241 . Subject content knowledge, essay writing, test taking, independent study skills, reading 243, note taking and tutorial work 242 .

Note2: 1=strongly disagree, $5=$ strongly agree.

${ }^{*} \mathrm{p}<.05$ (two-tailed tests

${ }^{* *} \mathrm{p}<.001$ (two-tailed tests)

As one participant observed:

I feel that coming straight out of Grade 12 to university did not prepare me for university because I had no idea about subjects like Psychology and Sociology etc. I first chose Math which I ended up hating. If I had had more time to study different things, I could have avoided the mess I've gotten myself into switching my major and making up classes. (Female, Grade 12) 
A male respondent related a similar experience:

I feel that I have missed out on opportunities because I had more limited time in high school than those students that went through OAC's. I would have preferred an extra year to take more classes than just the ones I needed to get into university. I also feel that with more time I could have focused on my classes than just getting good enough marks to get into university. (Male, Grade 12)

Moreover, a number of grade 12 entrants indicated that they felt an extra year of high school would have provided them with the opportunity to gain an additional level of maturity. Representative statements included the following, "As a student entering university at the age of 17, I find the transition difficult because I am younger than most people and my maturity level is, in general, barely high enough to handle university life" (Female, Grade 12), and "I truly don't feel high-school prepared me for university. I know some people who graduated (gr. 12) last year but had to go back to high school because they were either unprepared (courses) or they didn't feel they were mature enough to handle it" (Female, Grade 12). Students who had been admitted through the OAC route expressed a similar point of view in that they were appreciative of the extra year they spent in high school. As they commented, "I thought that my OAC year gave me another year to grow and mature. I think that if I would have graduated from gr. 12, I would have stayed an extra year anyway"(Female, $\mathrm{OAC}$ ), "I found through to both students graduating from OAC and grade 12 a difference in levels of maturity, essay writing skills and study habits" (Female, OAC) and "Take OAC or a $5^{\text {th }}$ year of high school. 17 year olds are far too immature to be here on average" (Male, OAC).

As indicated earlier in Table 2, survey data pointed to two specific areas of difference in the two groups' perceptions regarding their preparation for the academic challenges of university: (a) note-taking, and (b) the development of independent research skills. In the case of the former, the mean for Grade 12 was $2.77(\mathrm{SD}=1.21)$ and $3.37(\mathrm{SD}=$ 1.28 ), for OACs, $t=-3.52, \mathrm{p}<.001$. For the latter, the means for Grade 12 and $\mathrm{OAC}$ entrants were $3.38(\mathrm{SD}=1.08)$ and $3.66(\mathrm{SD}=1.13), t=-3.22$, 
$\mathrm{p}<.001$ respectively, indicating that participants admitted on the basis of completing Grade 12 tended to feel less well prepared than their OAC peers in these areas. Specific participant comments regarding the acquisition of note-takings skills included, "Should have prepared us for note taking a lot better" (Male, Grade 12), "They should have taught us more about note taking and testing at the University level, we were thrust into a whole new world; its completely opposite compared to high school" (Female, Grade 12), and "Note-taking in high school is completely different compared to university. Students should have training on how to take lecture-style notes." (Female, Mature).

Participants also alluded to the need for further preparation in the independent research skills required at the university level. As they indicated, "Teachers in high school should have done (had) more focus upon format, essays and research" (Female, OAC), and "Prepare high school students for reading because there is a lot more reading independently in university than high school" (Female, Grade 12).

\section{Preparation for the Social Aspects of University Life}

As indicated in Table 3 below, the survey instrument also inquired into participants' perceptions regarding their preparation for meeting the challenges posed by the university social milieu. These included following: (a) the degree to which participants felt that their high school education had provided them with information regarding university student life and not just academic training; (b) the extent to which they found it easy to participate in the social life of the universities they attended; (c) the ease with which they met and became acquainted with other students; (d) and perceptions of social isolation within the university community.

Regarding the aforementioned variables, both $\mathrm{OAC}$ and Grade 12 respondents reported similar experiences with respect to their adjustment to the university social milieu. The notable exception was in the extent to which participants found it easy to meet and become acquainted with other students on campus. Data analysis revealed that OAC entrants found this aspect of their transition to university life easier than did their Grade 12 counterparts. The mean for OAC participants was $3.95(\mathrm{SD}=.96)$ compared to 3.66 for Grade $12, t=-2.22, \mathrm{p}<.05$. 
Table 3

Social Adaptation to University

\begin{tabular}{|c|c|c|c|c|c|}
\hline \multirow[b]{2}{*}{ Variable } & \multicolumn{2}{|c|}{$\mathrm{OAC}$} & \multicolumn{2}{|c|}{ Grade 12} & \multirow[b]{2}{*}{$t$} \\
\hline & Mean & $\begin{array}{l}\text { Standard } \\
\text { Deviation }\end{array}$ & Mean & $\begin{array}{l}\text { Standard } \\
\text { Deviation }\end{array}$ & \\
\hline $\begin{array}{l}\text { Information on } \\
\text { university life }\end{array}$ & 3.19 & 1.14 & 3.20 & 1.14 & .04 \\
\hline $\begin{array}{l}\text { Participation in campus } \\
\text { social life }\end{array}$ & 3.58 & 1.16 & 3.29 & 1.14 & -1.84 \\
\hline $\begin{array}{l}\text { Ease in meeting new } \\
\text { people }\end{array}$ & 3.95 & .96 & 3.66 & 1.00 & $-2.22^{*}$ \\
\hline Feelings of isolation & 2.53 & 1.22 & 2.55 & 1.26 & .11 \\
\hline
\end{tabular}

Note 1: Degrees of freedom for information on university life was 243 , for remaining variables 242 .

Note 2: $1=$ strongly disagree, $5=$ strongly agree

${ }^{*} \mathrm{p}<.05$ (two-tailed test)

These results were reflected in subjects' open-ended responses as well, with participants often citing the differential of an additional year of secondary school as being an instrumental factor.

There is one girl in our house who came to university when she was 17 and straight out of grade 12, who is very uncomfortable here and doesn't seem to be having much fun. She isn't very social as most people we live with are a year older than her and I am confident that this is due to her only completing grade 12 . (Female, OAC)

A similar observation was made by a Grade 12 graduate who stated, "In question 20 I changed my answer because while it is easy to participate in many activities, a large part of social activities include going to the bar. Being 18, I cannot participate in these activities" (Female, Grade 12). Other representative comments included, "Some people are finding themselves too young (17) and are not included in many university activities because of this age difference" (Female, OAC), and "I think the biggest transition 
into University is realizing that you are alone in the world" (Male, OAC). Others thought that their high school could have done more to prepare them for the social aspects of university life. Specifically, "I thought that my high school teachers didn't focus enough on the social aspects of university life (learning to live with other people, time management, etc." (Female, $\mathrm{OAC}$ ), and "Academically the transition works. However, preparations for daily life should be taught to high schoolers" (Male, Grade 12).

\section{DISCUSSION AND CONCLUSIONS}

In many respects the first-year students who participated in this study shared a number of common characteristics. All participants reported having been capable students in high school; about half (regardless of whether they were Grade 12 or OAC graduates) reported living at home and the other half in university residence; and about half of the respondents did not work during the first semester of their university studies. As one might expect, since the Grade 12 entrants were a year younger than their OAC counterparts, the two groups differed significantly in mean age, the difference being one calendar year.

In terms of their adjustment to post-secondary studies, these two groups were somewhat similar, as has already been noted. However, these two groups differed significantly in how they perceived themselves as having been prepared for post-secondary studies. Even though, according to how the members of these groups reported their first-semester marks, there was no statistically significant difference in the academic performance between these groups, the OAC graduates reported a higher degree of satisfaction with their last year of secondary schooling as a preparation for tertiary education. Qualitative data analysis revealed that many OAC graduates felt that the extra year of high school enabled them to mature and to acquire mastery of the prescribed learning outcomes of the old, five-year secondary curriculum. In terms of writing, research, testtaking, note-taking, and study habits, OAC graduates tended to feel well prepared. In contrast, graduates of the new, four-year program felt that their preparation had been insufficient, especially in those same key areas. That many Grade 12 entrants perceived that their note-taking skills were deficient for deriving material from lectures should not be surprising, 
considering that the new Ontario Curriculum for Grades 11 and 12 of the four-year program de-emphasizes the stand-and-deliver mode of instruction that instructors in the old OAC curriculum tended to favour. The Ontario Curriculum documents for subjects as different as Grade 12 University-preparation Mathematics and English mention the exploration of "concepts individually and cooperatively and independently and with teacher direction; through hands-on activities" (OMET, 2000a, p.7) and indicate that students should be "devising research questions, identifying information needs and purposes in writing and developing research plans to acquire information and ideas from primary and secondary sources" (OMET, 2000b, p.43). The lecture method, which undoubtedly gave students many opportunities to develop note-taking skills, seems antithetical to this new hands-on, process-oriented approach to learning. It is not unreasonable, therefore, to speculate as to the existence of a link between this change of curricular emphasis and a perceived lack of note-taking skills on the part of participants who entered university directly from Grade 12.

Surprising, however, was the tendency on the part of Grade 12 graduates to report a degree of dissatisfaction with their independent research skills in view of the fact that the new Ontario Curriculum appears to emphasize discovery and problem-based learning, conducting independent learning projects and utilizing computer-based research skills. In fact, Grade 12 graduates tended to rate themselves as weaker than their OAC counterparts in this key area of university participation. Moreover, a number of Grade $12 \mathrm{~s}$ indicated that they believed that they lacked adequate preparation in the study skills conducive for success in university. They indicated that they experienced difficulty in coping with the reading and writing assignments that post-secondary instructors tend to give, a finding that suggests that the new curriculum may not be as demanding in these areas as was the old. It would appear that, contrary to the expectations of the Ontario Ministry of Education, Grade 12 graduates may not be as selfreliant and self-confident as learners when compared to graduates of the OAC program.

With respect to the social aspects of the high school to university transition former Grade 12 students also reported encountering a different 
experience from their OAC counterparts particularly in terms of meeting and becoming acquainted with new people within the university community. This finding, however, may be related to the mean age difference between the two age groups rather than any aspect of their previous secondary school experiences. Not being 19, and of legal drinking age, the former Grade $12 \mathrm{~s}$ reported being often excluded from a significant portion of campus socializing. Nevertheless, those participants who entered the university via the Grade 12 route indicated that they felt that their secondary school experience should have better prepared them for the social aspects of university life. How this transition might be accomplished is problematic since many high schools already organize campus visits for their senior students. Perhaps part of the socialization problem lies with a failure on the part of university administrators to anticipate the social needs of a student cohort composed of seventeen- and eighteen- year olds. Even though firstyear students in succeeding years will not belong to two distinctly different age groups, the question of how to integrate under-nineteen-year olds into campus life needs to be addressed if such students are to feel that they belong and are indeed welcome at Ontario universities.

Overall, the data generated by this study suggest that the preliminary results of Ontario's elimination of an official fifth year of secondary school for university-bound students are mixed at best. While there was no statistically significant difference between Grade 12 and OAC entrants in terms of end of first semester academic achievement, there were meaningful variations in other areas. Grade $12 \mathrm{~s}$, in general, tended to report feeling less well prepared for the transition to university when compared to their OAC counterparts, especially with regard to the acquisition of specific academic skills. Grade $12 \mathrm{~s}$ also reported being less at ease in adapting to the university social milieu. OAC entrants, on the other hand, were by and large grateful for the additional year they had spent in high school. Given this reticence on the part of some of the graduates of the new four-year program, it should not be surprising that, despite the best intentions of the Ministry of Education, a significant number of students are voluntarily returning for an additional year of secondary school studies (King, 2004), thus maintaining unofficially the Ontario tradition of a five-year high school program for students intending to pursue post-secondary education. 


\section{References}

Allan, L.G., Darling, A.L., Hughes, R.C. \& Rosenfeld, J.M. (1983). An examination of performance of first year students at an Ontario university: An admission perspective. The Canadian Journal of Higher Education, 13(3), 37-54.

Anisef, P. Baichman, E., Northrop, D., Rhyne D., \& Tilbert, J. (1986). Models and methodologies appropriate to the study of outcomes of schooling in Ontario's multicultural society. Toronto: Queen's Printer for Ontario.

Brody, M. (1986). Separation: High school to college. Paper presented at theAnnual Meeting of the National Association of College Admissions Counselors. Washington, D.C.

Casas, F.R. \& Meaghan, D.E. (1996). A study of repeated courses among secondary students in Ontario. Journal of Educational Rersearch, 90(2), 116-127.

Chaskes, J. (1996). The first-year student as immigrant. Journal of the Freshman Year Experience \& Students in Transition, 8(1), 79-91.

Fleming, W.G. (1971). Ontario's educative society, Vol. III: Schools, pupils, and teachers. Toronto: University of Toronto Press.

Gidney, R. D. (1999). From Hope to Harris: The reshaping of Ontario's schools. Toronto: University of Toronto Press.

Government of Ontario. (1950). Report of the Royal Commission on Education in Ontario. Toronto: Baptist Johnson, Printer to the King's

Government of Ontario. (1994). For the Love of Learning: Report of the Royal Commission on Learning. Toronto: Queen's Printer for Ontario.

Granger, B.G. (1994) What is Grade 14? Info. Winter, 19-20.

Grayson, J. Paul. (2003). The consequences of early adjustment to university. Higher Education, 46, 411-429.

Harackiewicz, J.M., Barron, K.E., Tauer, J.M., Elliot, A.J. (2002). Predicting success in college: A longitudinal study of achievement goals and ability measures as predictors of interest and performance from freshman year through graduation. Journal of Educational Psychology, 94(3), 562-875.

Holdaway, E.A. \& Kelloway, K.R. (1987). First year at university: Perceptions and experiences of students. The Canadian Journal of Higher Education. 37(1), 47-65.

Johnson, G.M. (1995). An ecological perspective on the transition of new university freshmen. Communication Education, 44(4), 336-352.

Jones, B.\& Frydenberg, E. (1998). Who needs help and when: Coping with the transition from school to university. Paper presented at the Annual Conference of the American Educational Research Association. Montreal, Canada. 
King, A.J.C. (2004). Double Cohort Study, Phase 3 Report. Toronto: Ontario Ministry of Education and Training

Larose, S., Robertson, D.U., Roy, R., \& Legault, F. (1998). Nonintellectual learning factors as determinants for success in college. Research in Higher Education, 39(3), 275-297.

Miles, M.B. \& Huberman, M.A. (1994). Qualitative Data Analysis. Thousand Oaks: Sage.

Ontario Department of Education (1968). Living and Learning: The Report of the Provincial Committee on Aims and Objectives of Education in the Schools of Ontario. Toronto: Ontario Department of Education.

Ontario Ministry of Education and Training (1995). Statement for Minister of Education and Training John C. Snobelen on Secondary School Reforms. Press Release, Nov. 2, 1995.

Ontario Ministry of Education and Training (2000a). The Ontario Curriculum Grades II and 12: Mathematics. Toronto: Queen's Printer for Ontario.

Ontario Ministry of Education and Training (2000b). The Ontario Curriculum Grades 11 and 12: English. Toronto: Queen's Printer for Ontario.

Pike, G. R. \& Saupe, J. L. (2002). Does high school matter? An analysis of three methods of predicting first-year grades. Research in Higher Education. 43(2), 187-207.

Sanders, L. \& Burton, J.D. (1996). From retention to satisfaction: New outcomes for a assessing the freshman experience. Research in Higher Education. 37(5), 555-567.

Sheppard, G. (1993). The sense of preparation: History students and high school-university articulation. Canadian Social Studies. 27(3), 107-110.

Smith, S. (1997). High school to college transition: An intervention to reduce student anxiety. Journal of College Admission. 157, 8-15.

Tinto, V. (1988). Stages of student departure: Reflections on the longitudinal character of student leaving. Journal of Higher Education. 59(4), 438-455. 